\title{
Competing through manufacturing: countering a product's liability of foreignness through mass customization
}

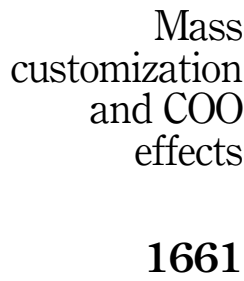

Received 5 November 2019 Revised 25 May 2020 7 July 2020

Accepted 1 August 2020

\section{Department of Business Administration, John Cabot University, Rome, Italy, and Enrico Sandrin and Cipriano Forza Department of Management and Engineering, University of Padova, Vicenza, Italy}

\begin{abstract}
Purpose - The operational capability of mass customization (MC) allows consumers to obtain products tailored to their idiosyncratic needs. This study aims to provide insights into the potential of this capability for countering a product's liability of foreignness - the negative effect of the out-group status of a product's country of origin (COO) on consumers' evaluations of the product.

Design/methodology/approach - Based on the social identity approach, it is hypothesized that this liability is reduced when a consumer product is mass-customized rather than standardized as per a mass-production strategy. This hypothesis is tested using a mixed between- and within-subject experiment.

Findings - When evaluating mass-produced sneakers, native German-speaking (Italian-speaking) South Tyrolean consumers rated the quality of Italian (German) sneakers significantly lower than that of German (Italian) sneakers. However, when the sneakers were mass-customized, this difference in perceived product quality was non-significant for both groups of consumers, supporting the research hypothesis.

Research limitations/implications - Future research could replicate this study in other samples, with other product types, $\mathrm{COO}$ s and countries of destination, as well as at different degrees of product customization. Practical implications - Business-to-consumer firms contemplating the development of their MC capability are made aware that the benefits of this operational capability might go beyond the typical advantages highlighted by the existing literature.

Originality/value - This paper joins the discussion on MC value by offering a theoretical explanation and empirical support for another mechanism through which the operational capability of MC can create value, at least in business-to-consumer industries: by countering a product's possible liability of foreignness and thus increasing perceived product quality in export markets.
\end{abstract}

Keywords Mass customization, Manufacturing/operations strategy, Country-of-origin effect, Social identity approach, Experimental study

Paper type Research paper

(C) Alessio Trentin, Thomas Aichner, Enrico Sandrin and Cipriano Forza. Published by Emerald Publishing Limited. This article is published under the Creative Commons Attribution (CC BY 4.0) licence. Anyone may reproduce, distribute, translate and create derivative works of this article (for both commercial and non-commercial purposes), subject to full attribution to the original publication and authors. The full terms of this licence may be seen at http://creativecommons.org/licences/by/4.0/ legalcode

The authors wish to thank the anonymous review team for their constructive and insightful comments and acknowledge the financial support from the University of Padova (project IDs BIRD199795, DOR1858802/18 and DOR1737878/17).

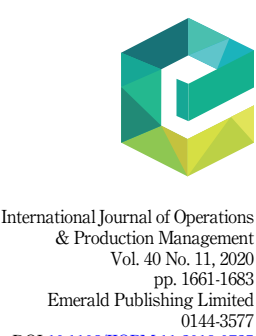

DOI 10.1108/IJOPM-11-2019-0725 
IJOPM

40,11

1662

\section{Introduction}

Mass customization (MC) denotes the operational capability to provide customized products/ services that fulfill each customer's idiosyncratic needs without substantial tradeoffs in cost, delivery and quality performance (e.g. Pine, 1993; Squire et al., 2006; Kortmann et al., 2014). Almost two decades ago, Lowson (2002) indicated MC as one of the major landmarks of modern operations and, indeed, "MC has evolved from being a niche competitive approach to becoming a widely adopted strategy" (da Silveira et al., 2016, p. 1). Industry 4.0 technologies promise to sustain this trend (Eyers et al., 2018; Koh et al., 2019). For example, digitalization creates the conditions for the empowerment of shop floor workers (Leyer et al., 2019) - an enabler, at least in many contexts, of MC (Sandrin et al.,2018) - and big data analytics provide opportunities for better mass personalization (Kache and Seuring, 2017). Reflecting its growing importance for the business community, $\mathrm{MC}$ has received increasing attention in academia (da Silveira et al., 2001; Fogliatto et al., 2012).

In particular, the strategic issue of what drives the value of MC has attracted growing interest (Fogliatto et al, 2012). The earliest studies emphasized two value creation mechanisms. The first is the reduction of the monetary and non-monetary costs borne by customers to obtain a customized product (Merle et al, 2010). This reduction derives from the mitigation of the negative effects of product customization on cost, delivery and quality performance (Merle et al.,2010) by virtue of technological and organizational solutions, such as product modularity and cross-functional coordination (e.g. Zhang et al., 2014). The second mechanism is the increase in the utilitarian benefit accruing to customers from the possession of the product (Piller et al, 2004; Merle et al., 2010). This increment stems from the closer fit between each customer's idiosyncratic preferences and the objective, functional or aesthetic features of the mass-customized product (Merle et al., 2010; Fogliatto et al., 2012; Sandrin et al., 2017). More recently, the literature has highlighted other possible sources of $\mathrm{MC}$ value, at least in businessto-consumer (B2C) industries, such as the product's symbolic qualities of uniqueness and selfexpressiveness - instead of its objective characteristics - and the positive emotions of enjoyment and pride experienced by customers when customizing a product - rather than the possession of the product itself (Merle et al., 2010; Fogliatto et al., 2012; Trentin et al., 2014; Sandrin et al, 2017). In summary, by progressively including additional sources of MC value, this line of inquiry has strengthened over time. Indeed, in their most recent review of the MC literature, Fogliatto et al. (2012) indicated that this is a promising area for further research.

The present study extends this stream of research by offering a theoretical explanation and empirical support for another mechanism by which MC can create value: by countering a product's possible liability of foreignness. When entering foreign markets, companies "may face an intangible barrier in the form of consumer bias on the basis of product origin" (Schooler, 1971, p. 71). For example, the tendency of consumers to favor domestic products has often been noted (Lantz and Loeb, 1996). Furthermore, in situations where domestic alternatives are not available, a positive bias toward products that originate in culturally similar countries has been found (Wang and Lamb, 1983; Watson and Wright, 2000). A common explanation for these findings is based on the notion of in-group favoritism (Lantz and Loeb, 1996; Watson and Wright, 2000), defined in the social identity approach (cf. Hornsey, 2008) as "the tendency to favor the in-group over the out-group in evaluations and behavior" (Tajfel and Turner, 1986, p. 13). The negative effect of the out-group status of a product's country of origin (COO) on customers' evaluations of the product itself is what we concisely refer to here as a product's liability of foreignness. The present study is the first to investigate, both theoretically and empirically, the potential of the operational capability of MC for countering this liability.

More specifically, the paper draws upon the social identity approach to develop the hypothesis that the product quality difference consumers perceive, under certain conditions, between a product originating in an in-group country and the same product coming from an out-group country is reduced when the product is mass-customized rather than mass-produced. 
To test this hypothesis, a mixed between- and within-subject experiment was designed, which involved two different COOs - Germany $v s$ Italy - for the same tangible product stimuli - either mass-customized or mass-produced sneakers - and 162, either native German-speaking or native Italian-speaking, South Tyrolean (ST) consumers. The results of the experiment showed that, when evaluating mass-produced sneakers, native German-speaking (Italian-speaking) STs rated the quality of German (Italian) sneakers significantly higher than that of Italian (German) sneakers, consistent with the notion of in-group bias. When sneakers were masscustomized, however, this difference in perceived product quality became non-significant for both groups of consumers, supporting the hypothesized bias-mitigation effect of MC.

This finding highlights another possible source of $\mathrm{MC}$ value: the mitigation of a product's possible liability of foreignness and the consequent increase in perceived product quality in export markets. This improves the understanding of how the operational capability of MC can support a firm's strategy of sales internationalization, which ultimately contributes to outlining - for this operational capability - an increasingly mature, "externally supportive" (Wheelwright and Hayes, 1985, p. 100) role in formulating and achieving an organization's strategic goals. Seen through the lens of the $\mathrm{COO}$ literature, the results of this study enrich the long-lasting discussion on the moderators of the COO effect. Pragmatically, this research speaks to B2C firms facing the challenge of persuading foreign customers to trust their products when similar goods are made by local competitors (cf. Brooks, 2019).

\section{Theoretical background and research hypothesis}

\subsection{Perceived product quality, country-of-origin effect and a product's liability of foreignness}

"Ever since the scientific management of quality became a field of expertise in the early 20th century, the definition of the word quality has appeared to be problematic" (Giroux, 2006, p. 1239). Conceptual ambiguity about quality and different approaches to defining this term have been repeatedly noted in the literature (e.g. Garvin, 1984; Reeves and Bednar, 1994; Golder et al., 2012). However, many scholars have convincingly argued that research should not aim at a single definition of quality; rather, different definitional perspectives must be consciously cultivated because each focuses on different dimensions of quality and is thus appropriate under different circumstances (Garvin, 1984; Reeves and Bednar, 1994; Sousa and Voss, 2002). Particularly, if the aim is to understand consumer behavior, then what is important - even for perfectly objective dimensions of quality, such as conformance to specifications - is the quality perceived by consumers (Stone-Romero et al., 1997). Predictably, customers' perceptions of product quality have been a paramount concern in the marketing literature (Golder et al., 2012), but their importance has also long been recognized in the field of operations management (OM) (e.g. Garvin, 1984). Stone-Romero et al. (1997) provide an extensive review of measures of perceived product quality.

From an information theoretic perspective, a product can be conceived as an array of information cues, which provide a basis for customers to develop various impressions of the product, including perceived product quality (Olson and Jacoby, 1972). Traditionally, a distinction has been made in the literature between intrinsic cues, which cannot be modified without also changing the physical characteristics of the product (e.g. rug fiber type), and extrinsic cues, which are product related but are not part of the physical product (e.g. rug price and warranty) (Olson and Jacoby, 1972; Bloemer et al., 2009). A product's COO is another example of an extrinsic cue, and the conscious or unconscious incorporation of this cue in the formation of customers' evaluations of the product is commonly referred to as the COO effect (Bloemer et al., 2009).

Traditionally, three types of mechanisms have been invoked to explain the COO effect: cognitive, affective and normative (Brijs et al., 2011). Cognitive mechanisms can take different forms, but in each customers, either deliberately or automatically (Herz and Diamantopoulos, 
IJOPM

40,11

1664
2013), use the COO cue to learn about the quality of a product (Brijs et al., 2011). One possibility is to use this cue as a "halo" to infer the unknown levels of intrinsic attributes of foreign products with which customers are not familiar (e.g. Han, 1989; Laroche et al., 2005). For instance, novice American consumers could rate the reliability of consumer electronics "Made in Japan" very high based on strong stereotypes of the country in which the products originate. Meanwhile, experienced American consumers could use the same COO cue as a "summary construct" to represent, in their memory, the knowledge they have previously acquired about the actual quality of various consumer electronic products "Made in Japan" and to readily retrieve such knowledge when evaluating other products of the same category from the same country (e.g. Han, 1989; Laroche et al., 2005). It is important to note that consumers have perceptions about how typical a certain product is of a given country (Spielmann, 2016) and evaluate products perceived as typical of a given country more favorably than atypical products with the same origin (Tseng and Balabanis, 2011). For example, although Japan has a generally positive image in Taiwan, Japanese refrigerators are perceived by Taiwanese consumers as more typical of Japan than Japanese teapots, thus enjoying more favorable evaluations (Tseng and Balabanis, 2011).

Besides cognitive processes, the COO cue can also trigger affective processes, evoking positive or negative feelings that influence product evaluation (Brijs et al., 2011; Laroche et al., 2005). An individual may have strong emotional connotations about a country for many different reasons, such as holidays spent there or the country's history and art (Verlegh and Steenkamp, 1999).

Finally, the COO cue can affect product evaluation through a normative mechanism involving a customer's inner norms and values (Brijs et al., 2011). For instance, an American consumer whose experience suggests that German cars are durable might cognitively infer that an Audi is a durable car because it originates in Germany and have no emotional response to Germany as a COO. However, the consumer's personal motive to maintain a positive self-concept, as explained in the next section, might constitute a liability for a foreign car, including an Audi, and this normative mechanism could lead the consumer to favor a car from his or her home country.

\subsection{Social identity approach and a product's liability of foreignness}

The social identity approach, comprising Tajfel's (1978) social identity theory and Turner et al.'s (1987) self-categorization theory, is a highly influential, theoretical explanation of intergroup relations and group processes (Hornsey, 2008). One central tenet of this approach is the existence of different levels of self-definition that are important to an individual's selfconcept (Hornsey, 2008). At the level of personal identity lie those "characteristics and behaviors (e.g. intelligent, hardworking) that differentiate one from others" (Reid and Daux, 1996, p. 1084). Personal identity is based on interpersonal comparisons (Hornsey, 2008) and does not depend on group membership (Gaertner et al., 2002). Yet, when the distinction between certain social categories becomes salient (e.g. when two males confront two females in debating an issue, as opposed to two males or two females confronting each other (Hogg and Turner, 1987)), another level of self-definition gets activated: the level of social identity (Hornsey, 2008). At this level lie those aspects of an individual's self-concept that derive from the social category, or categories, to which he or she perceives belonging (Tajfel and Turner, 1986). The individual's social identity describes what it is to be a category member and prescribes what kinds of attitudes, emotions and behaviors are appropriate in a certain context (Hornsey, 2008).

Another basic tenet of the social identity approach is the existence of a "functional antagonism" between different levels of self-definition, meaning that when one level becomes more salient, another level becomes less so (Hornsey, 2008, p. 208). For instance, when a certain social identity is activated, the individual comes to see himself or herself less as a 
unique personality, defined by individual differences, and more as an interchangeable exemplar of the social category of affiliation (Hornsey, 2008). This process of depersonalization is also referred to in the literature as "self-stereotyping" (Simon and Hamilton, 1994; Lantz and Loeb, 1998). The individual tends to think of himself or herself as having characteristics that are representative of the social category to which he or she perceives belonging (Brewer and Gardner, 1996). For example, the participants in Hogg and Turner's (1987) study characterized themselves as more typical of their gender when distinctions between males and females were made salient - i.e. when discussion took place between two men and two women - than when two people of the same gender confronted each other (Brewer and Gardner, 1996). In summary, the mere process of making "us $v s$ them" distinctions salient changes the way people see themselves (Hornsey, 2008).

From the distinction between group- and individual-based aspects of the self and from the assumption that individuals are motivated to have a positive self-concept, the social identity approach derives the prediction that people will strive to achieve, or to maintain, a positive social identity (Tajfel and Turner, 1986). People accomplish this goal by means of "favorable comparisons that can be made between the in-group and some relevant out-groups: the ingroup must be perceived as positively differentiated or distinct from the relevant out-groups" (Tajfel and Turner, 1986, p. 16). This motive for positive distinctiveness may lead to in-group bias (Turner and Reynolds, 2012), defined as "the tendency to favor the in-group over the outgroup in evaluations and behavior" (Tajfel and Turner, 1986, p. 13).

However, in-group favoritism is not an automatic and inevitable outcome of the process of social self-categorization (Turner and Reynolds, 2012). For instance, where status differences between two social groups are perceived by both groups as legitimate and/or stable, it is possible that neither "the inferior" nor the "superior" groups will show a tendency to favor the in-group over the out-group (Tajfel and Turner, 1986). Particularly, the subordinate group might internalize a widely accepted evaluation of itself as "inferior" and hence derogate itself and display a positive attitude toward the dominant out-group (Taifel and Turner, 1986). Conversely, in-group bias is expected to prevail when the subordinate group is able to be critical of, and see alternatives to, the status quo of intergroup relations (Tajfel and Turner, 1986; Hornsey, 2008).

From the above, it can be inferred that, when consumers confront two products of the same kind that originate in two different countries, one of which is either their motherland or a country culturally more similar to their motherland than the other, the $\mathrm{COO}$ cue primes the consumers' self-categorization according to the criterion of cultural affiliation. In turn, the activation of this social identity may lead the consumers to favor the product originating in the in-group country over the one coming from the out-group country.

\subsection{Operations strategy, mass customization and a product's liability of foreignness}

Since Skinner's (1969) pioneering work on the strategic role of the manufacturing function, the literature on operations strategy has grown substantially, and it has been repeatedly reviewed over the past four decades (e.g. Anderson et al., 1989; Swink and Way, 1995; Chatha and Butt, 2015). While much agreement exists regarding the decision areas that are of strategic importance to the manufacturing function (Rudberg and Olhager, 2003), the approaches for making manufacturing strategy decisions have been the subject of a longstanding debate (da Silveira and Sousa, 2010). Different, though interrelated and partially overlapping paradigms of choice have been advocated, each with its strengths and weaknesses (Voss, 1995, 2005). For the purposes of this study, the "competing through manufacturing" paradigm (Voss, 1995, p. 6), also referred to as the "capabilities" paradigm (da Silveira and Sousa, 2010, p. 1222), is particularly relevant. Advocates of this paradigm have suggested that the true objective of a manufacturing strategy is to build competencies for a sustainable competitive advantage (da Silveira and Sousa, 2010). 
IJOPM

40,11

1666
Four basic manufacturing capabilities have consistently been stressed in prior research low cost, quality, flexibility and delivery - but the discussion regarding their interrelationships has been heated (Boyer and Lewis, 2002). The notion of MC can be seen within the context of this debate (Squire et al., 2006), as the advent of MC was predicated on the assumption that "companies can overcome the traditional trade-offs" (Pine et al., 1993, p. 111) between product customization - a dimension of flexibility - and cost, quality and delivery performance (Squire et al., 2006). Accordingly, the choice of building the capability of overcoming these manufacturing trade-offs - i.e. the operational capability of MC - can be seen as an important part of a firm's operations strategy (Sousa and da Silveira, 2019), along with the set of consistent, structural and infrastructural choices required to build this capability (cf. Boyer and Lewis, 2002). The question of how to develop the operational capability of $\mathrm{MC}$ has been investigated extensively (for a review of prior research, see Fogliatto et al. (2012) and Suzic et al. (2018)), with an initial focus on technological enablers that has progressively broadened to also encompass organizational enablers (Trentin et al., 2019). Another question that has attracted growing interest, as observed in Section 1, is what drives the value of $\mathrm{MC}$, especially in $\mathrm{B} 2 \mathrm{C}$ industries (for a review of prior research, see Merle et al. (2010) and Fogliatto et al. (2012)).

The diffusion of $\mathrm{MC}$ in $\mathrm{B} 2 \mathrm{C}$ industries has been linked to the growing importance of subjectivity in consumption (Addis and Holbrook, 2001). Possessing a product that reflects the individual, idiosyncratic aspects of a consumer's self-concept is regarded as one of the fundamental benefits of MC from the consumer's perspective (Chang et al., 2009; Merle et al., 2010; Sandrin et al., 2017). The possibility of self-expression offered by a mass-customized product is expected to make the consumer's personal identity more salient while he or she is customizing the product. According to the notion of functional antagonism posited by the social identity approach (Hornsey, 2008), the salience of the consumer's personal identity increases at the relative exclusion of his or her social identity as a member of his or her group of affiliation. Therefore, $\mathrm{MC}$ is expected to produce a shift in the consumer's identity from the social to the personal level. This shift alleviates the pressure on the consumer toward positive distinctiveness of his or her group of affiliation, thus mitigating the tendency to favor (disfavor) a product based on the in-group (out-group) status of its $\mathrm{COO}$ in a given decision situation.

Interestingly, this rationale closely echoes Swaminathan et al.'s (2007) logical argument corroborated by experimental evidence - that the situational priming of personal identity ( $v s$ social identity) mitigates the positive influence of local branding ( $v s$ foreign branding) on brand equity. Indirectly, our logic is also supported by Gürhan-Canli and Maheswaran's (2000) argument - also corroborated by experimental evidence - that domestic products are less likely to be preferred over foreign products in individualist cultures, where people tend to be emotionally detached from the in-group, than in collectivist cultures, where an individual's self is defined in terms of others, and behavior is regulated by group norms. Further support for our argument can be found in prior research on the role of psychological ownership in consumer behavior. Psychological ownership is a psychological state in which an object is experienced as having a close connection with an individual's self (Pierce et al., 2003), thus becoming a part of his or her "extended self" (Belk, 1988, p. 139). This object-self connection may involve an individual's personal identity as well as his or her social identity (Belk, 1988; Gineikiene et al., 2017). Accordingly, psychological ownership may not only be an individuallevel phenomenon but also a group-level one (Pierce and Jussila, 2010). For example, preferences for domestic products have recently been explained by Gineikiene et al. (2017) using psychological ownership at the group level. As the investment of energy required from a consumer to self-customize a product has been argued to foster psychological ownership at the individual - rather than group - level (Franke et al., 2010), the preference bias in favor of domestic products is thus expected to diminish when products are mass-customized rather than mass-produced. 
Based on these arguments, we posit the following research hypothesis:

Assuming that consumers rate the quality of a product originating in an in-group country higher than the quality of the same product from an out-group country, this perceived product quality difference is reduced when the product is mass-customized instead of being mass-produced.

\section{Method}

The research hypothesis was tested using a $2 \times 2 \times 2$ mixed between- and within-subject experimental design (cf. Field and Hole, 2003; Seltman, 2012). The study included one withinsubject factor, $\mathrm{COO}$ (Germany vs Italy), and two between-subject factors, product type (masscustomized $v s$ mass-produced product) and ethnic affiliation (native German-speaking $v s$ native Italian-speaking ST). The choice of a within-subject design has the advantage of increasing the statistical power of the experiment without reducing the generalizability of its results (Seltman, 2012) by removing subject-to-subject variation from the investigation of the relative effects of different COOs. This advantage, however, may come at the price of a slew of confounding factors potentially introduced by a within-subject design, such as experimenter demand effects - also known as demand artifacts - and sensitization to the within-subject factor (Charness et al., 2012). The procedures followed in this study to reduce these disadvantages are described in Section 3.4. Importantly, a within-subject experiment, when carefully designed to mitigate its drawbacks, has another major advantage - increased realism - as much of consumer behavior is analogous to a within-subject experiment (D'Alessandro and Pecotich, 2013).

\subsection{Sample}

Data were collected through an intercept survey conducted in one of the major shopping centers in South Tyrol, the northernmost Italian province, at the borders with Austria and Switzerland. The choice of sampling ST consumers was motivated by two reasons. First, the ST population is mainly composed of two distinct ethnic groups: German- and Italian-native speakers (Taverna et al., 2011). Second, the extant literature provides evidence that the relations between the two groups remain conflicting, at least to some extent, and that native Italian-speaking STs, who have come to feel they suffer a second-class status, are able to be critical of the perceived differences of status with respect to the German-speaking group (e.g. Capozza and Manganelli Rattazzi, 1999; Costarelli and Colloca, 2004). Therefore, in accord with the social identity approach (Tajfel and Turner, 1986; Hornsey, 2008), both groups are expected to feature in-group bias.

Following Balabanis et al. (2002), we attempted to reduce sample selection bias by collecting data over the whole course of the day (from morning to evening) and on different days of the week. Passersby were stopped at random and asked to participate in the survey. In total, 165 people agreed to participate.

Participants were classified as native Italian- or German-speaking STs using Laroche et al.'s (2003) validated procedure to measure ethnic affiliation. Specifically, participants were asked to give a distribution in terms of the percentage of time - from 0 (never) to 100 (all the time) - that they use Italian, German or another language during 11 activities (at home, with relatives, with friends, reading newspapers, watching television, listening to the radio, reading magazines, reading books, while shopping, at work and at school). The scores on this language scale were subsequently used as input variables in a cluster analysis. Specifically, a hierarchical method based on the Ward algorithm was adopted to separate the two clusters. To handle the large number of missing data on the use of language at work and school, likely because most people are either working or going to school, these activities were combined into a single activity. With this approach, it was possible to allocate 162 participants to the 
IJOPM

40,11

two clusters, thus classifying 85 respondents as native Italian-speaking STs and 77 as native German-speaking STs [1]. Potential differences between the two clusters in the demographics reported in Table 1 were analyzed using chi-square tests. No significant differences were found at $p<0.10$, indicating that the two clusters were comparable in terms of gender, age, education and household income.

\subsection{Country of origin selection}

Two source countries were selected, so that we could observe a product's liability of foreignness in both groups of consumers comprising our sample. Besides Italy - the motherland of native Italian-speaking STs - we did not select Austria - the home country of native German-speaking STs - but rather Germany, for two reasons. First, this choice did not appear to conflict with the objective of observing the liability-of-foreignness phenomenon in the group of native German-speaking STs, as Austria and Germany belong to the same cultural cluster - the Germanic Europe cluster - while Italy is part of the so-called Latin Europe cluster (e.g. House et al., 2004). Therefore, the task of evaluating two products of the same kind that originate, respectively, in Italy and Germany was expected to activate, for native German-speaking STs, their social identity as members of Germanic Europe as opposed to Latin Europe. Stated otherwise, the evaluation task was expected to lead native German-speaking STs to see Germany as the in-group country and Italy as the out-group one, even though Germany was not their motherland.

Second, the selection of Germany and Italy instead of Austria and Italy alleviated the risk that cognitive mechanisms would have a confounding effect in the experiment, for several reasons. First, both Germany and Italy were in the top ten countries with the highest nominal gross domestic product at the time this research was designed, while Austria was only $28^{\text {th }}$ (International Monetary Fund World Economic Outlook, 2015). In addition, both "Made in Germany" and "Made in Italy" were in the top five of the "Made in" ranking list according to FutureBrand (2014), while "Made in Austria" was not even in the top 20. Finally, both Germany and Italy were more likely to be renowned for the MC capabilities of some of their companies (cf. Moser and Piller, 2006).

\begin{tabular}{llcc}
\hline Variable & & $\begin{array}{c}\text { Cluster 1 (native Italian- } \\
\text { speaking STs) } \\
\%\end{array}$ & $\begin{array}{c}\text { Cluster 2 (native German- } \\
\text { speaking STs) } \\
\%\end{array}$ \\
\hline Gender & Female & 50.6 & 45.5 \\
Age & Male & 49.4 & 54.5 \\
& Less than 35 & 37.6 & 49.4 \\
& 35-49 & 38.8 & 32.5 \\
Education & 50-65 & 20.0 & 16.9 \\
& More than 65 & 3.5 & 1.3 \\
& Middle school & 21.2 & 22.1 \\
Household Income & High school & 56.5 & 61.0 \\
(EUR) & University & 14.1 & 11.7 \\
& No answer & 8.2 & 5.2 \\
& Less than & 17.6 & 16.9 \\
& 20,000 & & 42.9 \\
& 20,000-39,999 & 29.4 & 16.9 \\
& 40,000-59,999 & 24.7 & 23.4
\end{tabular}

Table 1.

Sample demographics
Note(s): ${ }^{\text {a }}$ Little's test was performed to check if those responses were missing completely at random (MCAR). The resulting $p$-value was non-significant $(p>0.10)$, indicating that the responses were MCAR 


\subsection{Product selection}

Sneakers were selected as a product stimulus for two reasons. First and foremost, this choice reduced the risk that ST consumers' perceptions of how typical of Italy or of Germany a certain product is would have a confounding effect in the experiment. To assess this risk in the present study, a pre-test was conducted with 62 potential customers randomly selected from both native Italian- and German-speaking STs. Each respondent was asked to rate sneakers on two, seven-point, bipolar semantic differential scales ranging from "not a typical Italian (German) product" to "a typical Italian (German) product." For each respondent, the difference between these two ratings was calculated. Subsequently, the null hypothesis that this difference is equal to zero was tested using one-sample $t$-test in each of the two subsamples of native Italian- and German-speaking STs, respectively. Assumptions required for the $t$-test were not violated. The results suggested that sneakers were not considered a more typical product of Italy or of Germany by either native Italian-speaking STs $(t(25)=-0.787$, $p=0.439)$ or native German-speaking STs $(t(35)=0.142, p=0.888)$.

Second, sneakers are a type of shoe that has experienced an exponential increase in product variety over time (Aichner and Coletti, 2013). Thus, it is not by chance that sneakers have been selected for other quantitative studies on B2C MC (e.g. Merle et al., 2010; Sandrin et al., 2017).

\subsection{Data collection procedure}

The experiment made use of physical products, in addition to verbal and graphical product descriptions, as the latter have been criticized for their lack of realism and their inflation of the COO effect (Peterson and Jolibert, 1995). Specifically, each participant in the experiment was presented two pairs of different, non-branded sneaker models - hereafter referred to as Model A and Model B - which were associated with the two COOs under examination. The two models had a similar shape but were manufactured by different producers, had different colors and differed slightly in attributes such as the number of zippers and the number of holes for shoelaces. To ensure that every participant noticed the COO cues, the COOs of the two pairs of sneakers were communicated explicitly, by writing the phrase "Made in Italy" or "Made in Germany" on the questionnaire, and implicitly, by placing the respective country flag next to the image of the sneaker on the questionnaire. In addition, the $\mathrm{COO}$ was indicated orally by the interviewer.

Associating the two COOs with two different models of sneakers enabled camouflaging the only within-subject factor in the experiment (i.e. COO). This helped reduce both sensitization to this factor and experimenter demand effects, i.e. the likelihood that participants "discovered" the purpose of the study and thus attempted to answer in a way that they thought would please the experimenters. This advantage, however, came at the price of possible confounding effects that could derive from the slight differences in the two sneaker models. To address this potential source of bias, the $\mathrm{COO}$ of Model A and the $\mathrm{COO}$ of Model B were exchanged in the experiment in such a way that approximately $50 \%$ of the participants assessed Model A "Made in Italy" and Model B "Made in Germany," while the remaining ones evaluated Model A "Made in Germany" and Model B "Made in Italy"[2].

For each model, the stimulus in the "MC" condition included an informational sheet showing the various customization options and, for illustrative purposes, the image of one example of a mass-customized sneaker - the same that was used as a tangible product stimulus (Figures A1 and A2). All the customization options were explained to each subject in the "MC" condition to ensure that they were fully understood. Furthermore, participants were informed that each sneaker model could be customized according to their personal needs by making a choice for each option, and they were asked to express their preferences.

As the images of the physical products and the associated COOs were to be printed on the questionnaire, four different versions of the questionnaire were developed (Table 2), each
Mass and $\mathrm{COO}$ effects

1669 
IJOPM 40,11

\section{0}

available in both Italian and German. The four versions contained exactly the same set of items aimed to measure ethnic affiliation (Section 3.1) and perceived product quality (Table 3). For each participant, the version of the questionnaire was assigned randomly by having a computer individually generate a random number from 1 to 4 for each subject. To confirm the random assignment of subjects to the four different questionnaire versions, chi-square tests were performed for the demographics reported in Table 1. No significant differences were found $(\phi>0.10)$.

Each participant received both pairs of sneakers and was asked to assess the product quality of each pair. There was no time limitation to accomplish the evaluative task, and participants were prohibited to speak to other participants or to personal companions.

\section{Results}

Measurement quality was assessed via confirmatory factor analysis (CFA) using LISREL 8.80. The CFA model showed a good fit with the data: $\chi^{2}(\mathrm{df})=26.548(19), X^{2} / \mathrm{df}=1.397$; comparative fit index $(\mathrm{CFI})=0.993$, root mean square error of approximation (RMSEA) $(90 \%$ $\mathrm{CI})=0.0399(0.0 ; 0.0839)$. The CFA results (Table 3$)$ showed acceptable unidimensionality, convergent validity and reliability of the multi-item measurement scale of perceived product quality for both Italian and German sneakers. As the scale was unidimensional in both cases,

\begin{tabular}{llll}
\hline Product type & & \multicolumn{2}{c}{ Product's COO } \\
\hline & & Italy & Germany \\
Mass-produced sneakers & Questionnaire version 1 & Model A & Model B \\
& Questionnaire version 2 & Model B & Model A \\
Mass-customized sneakers & Questionnaire version 3 & Model A & Model B \\
& Questionnaire version 4 & Model B & Model A \\
\hline
\end{tabular}

Table 2.

Questionnaire versions

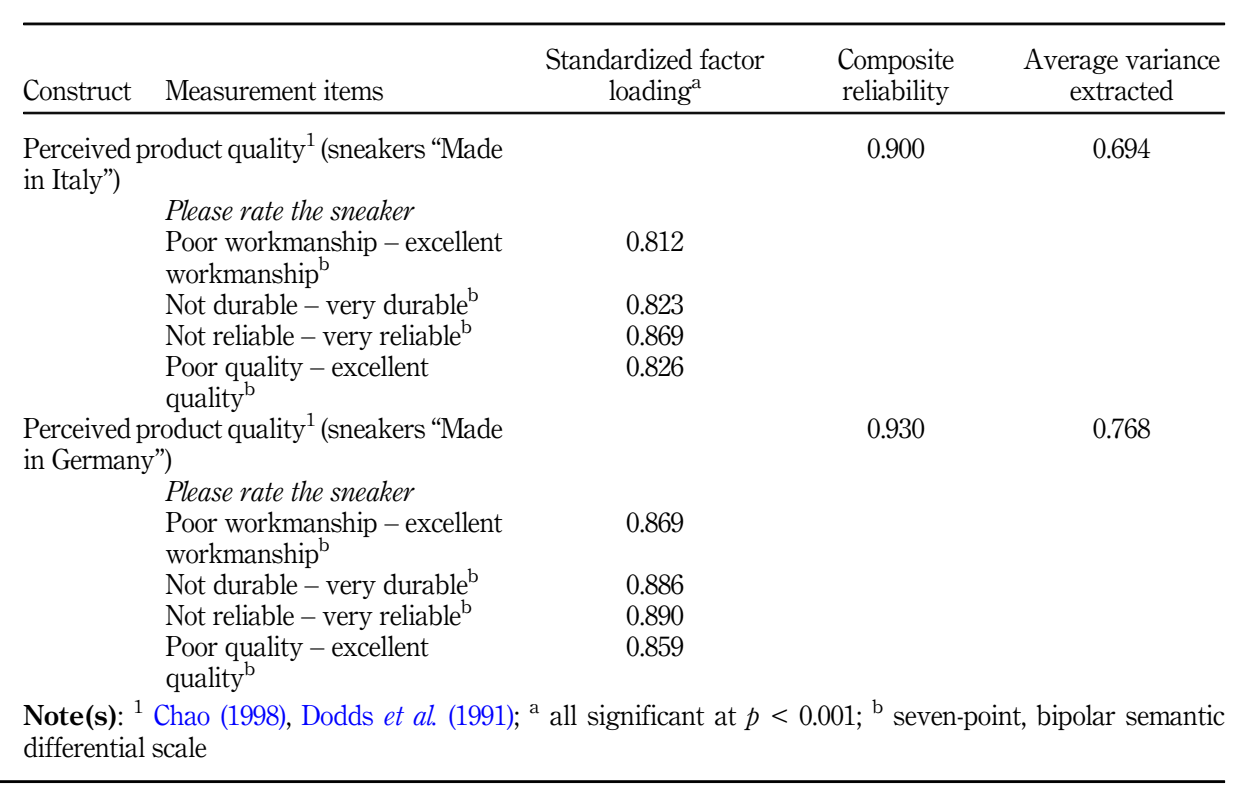

Table 3.

Measures and CFA results 
we decided to use summated scales in the subsequent analyses, in accord with Nasser-Abu Alhija and Wisenbaker (2006).

To test the research hypothesis, a $2 \times 2 \times 2$ mixed analysis of variance (ANOVA) was performed using SPSS 22. First, violations of the assumptions required for the analysis were checked for. The independence assumption was satisfied because each participant had answered the questionnaire without speaking to other participants. Likewise, the assumption of homogeneity of variance across the eight groups was met, as Levene's test was nonsignificant $(p>0.10)$. The sphericity assumption was equally satisfied because the only withinsubject factor - COO - had only two levels (Seltman, 2012). As for the normality assumption, Shapiro-Wilk tests were non-significant $(p>0.10)$ for five of the eight groups, but they were significant for the remaining three. Although this finding suggested violation of the normality assumption, the ANOVA was deemed appropriate for the analysis of the data because it is robust to deviations from normality for sample sizes greater than five (Norman, 2010).

The results of the ANOVA showed a significant, three-way interaction effect between the product's COO (Germany vs Italy), the participant's ethnic affiliation (native German- vs native Italian-speaking ST) and the product type (mass-customized vs mass produced sneakers) $(F(1,158)=11.197, p<0.01$, partial eta square $=0.066)$. This result indicated that the impact of the interaction between $\mathrm{COO}$ and ethnic affiliation on perceived product quality was contingent upon the product type. To understand whether this moderating effect was in line with our research hypothesis, we performed pairwise comparisons, the results of which are reported in the following and are graphically depicted in Figures 1 and 2.

When sneakers were mass-produced and were rated by native Italian-speaking STs, the perceived quality of Italian sneakers was, on average, higher than that of German sneakers (Figure 1a), and this difference was significant $(p<0.001)$. Similarly, when the same shoes were evaluated by native German-speaking STs, the mean difference in perceived product quality between German and Italian sneakers was positive (Figure 1b) and significant $(\phi<0.05)$. Taken together, these findings indicated that, when evaluating mass-produced sneakers, native Italian-speaking (German-speaking) STs favored the sneakers from Italy (Germany) - the in-group country in the evaluation task - over those from Germany (Italy) the out-group country. In other words, the sneakers from the out-group country suffered from the liability of foreignness across both native Italian- and German-speaking STs.

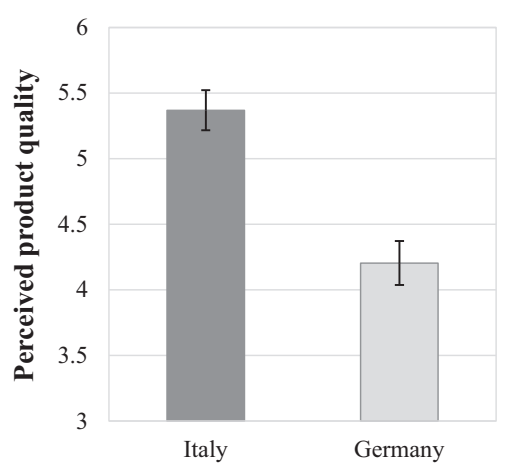

Country of origin

(a)

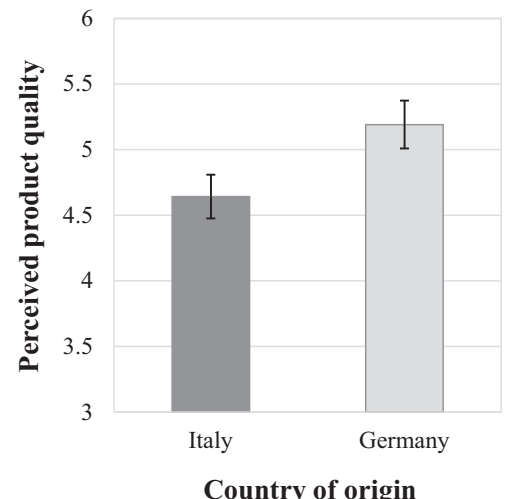

(b)

- Mass-produced sneakers

- Native German-speaking South Tyroleans $\begin{array}{r}\text { Mass } \\ \text { customization } \\ \text { and COO } \\ \text { effects } \\ \mathbf{1 6 7 1} \\ \hline\end{array}$

$\begin{array}{r}\text { Mass } \\ \text { customization } \\ \text { and COO } \\ \text { effects } \\ \mathbf{1 6 7 1} \\ \hline\end{array}$

$\begin{array}{r}\text { Mass } \\ \text { customization } \\ \text { and COO } \\ \text { effects } \\ \mathbf{1 6 7 1} \\ \hline\end{array}$

$\begin{array}{r}\text { Mass } \\ \text { customization } \\ \text { and COO } \\ \text { effects } \\ \mathbf{1 6 7 1} \\ \hline\end{array}$

$\begin{array}{r}\text { Mass } \\ \text { customization } \\ \text { and COO } \\ \text { effects } \\ \mathbf{1 6 7 1} \\ \hline\end{array}$
- Mass-produced sneakers

- Native Italian-speaking South Tyroleans 
IJOPM

40,11

\section{2}

Figure 2.

Pairwise comparisons between means of perceived product quality for masscustomized sneakers. Error bars show the standard error of the means

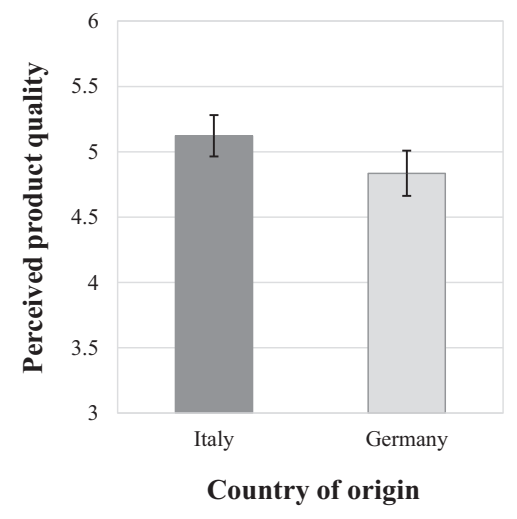

(a)

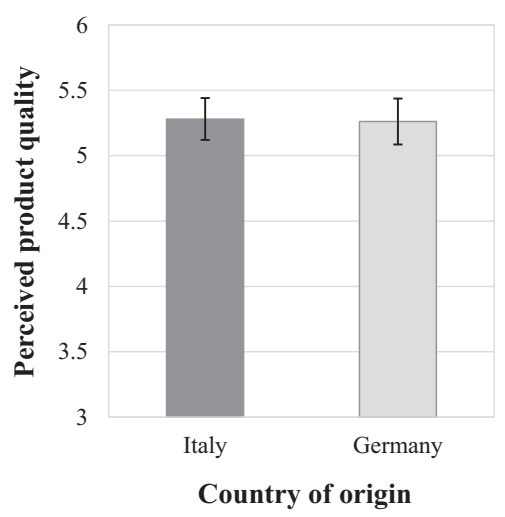

(b)
- Mass-customized sneakers

- Native Italian-speaking South Tyroleans
- Mass-customized sneakers

- Native German-speaking South Tyroleans

However, when native Italian-speaking STs rated mass-customized sneakers, no statistically significant difference was found $(\phi>0.10)$ in the mean perceived product quality between Italian and German sneakers (Figure 2a), consistent with the research hypothesis that MC mitigates a product's liability of foreignness. Likewise, when mass-customized sneakers were evaluated by native German-speaking STs, no statistically significant difference was detected $(\phi>0.10)$ between the average values of perceived product quality for German and Italian sneakers (Figure 2b). In summary, support for the hypothesized bias-mitigation effect of MC was found in both groups of ST consumers.

\section{Discussion and conclusions}

\subsection{Theoretical implications}

By bridging the two, previously unrelated research streams on $\mathrm{MC}$ and $\mathrm{COO}$, the present study contributes to each of these two lines of inquiry in a unique manner. Regarding MC, this paper joins the discussion on MC value and the economics of MC (cf. Fogliatto et al., 2012). This debate has not been overlooked by OM journals, which have contributed to a better understanding of the sources of MC value (e.g. Piller et al., 2004; Merle et al., 2010, Fogliatto et al., 2012), sometimes by building upon theories from other fields, such as the uniqueness theory from social psychology and the self-concept theory from consumer psychology (cf. Merle et al., 2010). This borrowing can be seen as part of a broader phenomenon revealed by Pilkington and Meredith (2018), i.e. the trend of leading OM journals increasingly referencing knowledge from other disciplines, such as marketing and strategy. In line with this trend, the present paper draws upon the social identity approach - from the field of social psychology to hypothesize another mechanism through which $\mathrm{MC}$ can create value: by countering a product's possible liability of foreignness. By finding empirical support for this hypothesis, the present paper not only advances knowledge of the drivers of MC value but also improves the understanding of the role that MC can play in a firm's sales internationalization strategy, at least in B2C industries. Prior research (e.g. Calantone et al., 2004) has observed that a company's expansion into foreign markets inherently increases the firm's product variety, assuming that the company decides to adapt the physical characteristics of its products for the export markets - in an attempt to better satisfy the needs and wants of customers in 
different countries - or is forced to adapt its products to comply with local regulations. Under these assumptions, it is apparent that the operational capability of MC supports sales internationalization by preventing increased product variety from significantly impairing cost, delivery and quality performance. However, the results of this paper suggest another, perhaps less obvious way that the operational capability of MC can enhance the profitability of an export venture: by mitigating a product's possible liability of foreignness and, thus, increasing perceived product quality in export markets. This additional link between operations and marketing strategies can be interpreted through the lens of the "competing through manufacturing" paradigm in the field of operations strategy (Section 2.3). In its simplest form, this paradigm argues that manufacturing capabilities should align with the business strategy that others have defined (Voss, 1995; Wheelwright and Hayes, 1985). While this may be a worthy first step for many firms, a higher stage of competitive effectiveness of manufacturing requires this function to take a more proactive role - an equal role, as compared with other functions - in defining the business strategy (Wheelwright, 1984; Wheelwright and Hayes, 1985). In this most progressive stage, "competitive strategy rests to a significant degree on a company's manufacturing capability" (Wheelwright and Hayes, 1985, p. 103), and manufacturing is "centrally involved in major decision-making in other functions" (Barnes and Rowbotham, 2004, p. 706). By suggesting that the role played by the operational capability of MC in the definition of a firm's sales internationalization strategy can be more proactive than is implied by the extant literature, the present paper confirms the validity of Hayes and Wheelwright's (1984, p. 41) challenge to "the idea that the role of the manufacturing function is simply to assist in implementing the strategy that others have developed." By doing so, the present paper ultimately contributes to outlining an increasingly mature - externally supportive, according to Wheelwright and Hayes's (1985) terminology role (Barnes and Rowbotham, 2004) of the operational capability of MC.

Another connection of the present study's results to the operations strategy literature involves one of the most commonly cited strategic decisions for the operations function: where to locate a firm's manufacturing facilities (Rudberg and Olhager, 2003). Prior research has identified many factors that influence this decision (cf. Johansson and Olhager, 2018), including customers' characteristics (e.g. MacCarthy and Atthirawong, 2003), such as their inner norms and values. As discussed in Section 2.2, consumers' personal motive to maintain a positive self-concept may explain their bias toward domestic products or, in the absence of domestic alternatives, toward products that originate in culturally similar countries. Establishing a manufacturing presence in a foreign market has been suggested as a possible strategy to counter this bias (e.g. Cohen and Lee, 1989; Lewin et al., 1998). The results of the present study indicate that the operational capability of MC may also alleviate this bias. Thus, this possibility is another factor that should be considered in manufacturing location decisions, at least when firms are expanding into foreign markets.

Seen through the lens of the COO literature, the results of this study enrich the discussion on the moderators of the COO effect. Twenty-five years ago, Peterson and Jolibert (1995), considering the difficulty of making broad generalizations regarding the influence of the $\mathrm{COO}$ cue on consumers' product evaluations, were the first to carry out a meta-analysis of the COO effect to identify moderating variables affecting the occurrence, direction and magnitude of this effect. Since then, other researchers have responded to their call for more research on the moderators of the $\mathrm{COO}$ effect, which have come to include a broad set of factors, including whether subjects are presented only with information about a product's $\mathrm{COO}$ or also with other intrinsic and/or extrinsic cues (Verlegh and Steenkamp, 1999). Interestingly, none of the studies in which the $\mathrm{COO}$ cue has been presented along with intrinsic product information has considered the possibility for a consumer to configure the product according to his or her idiosyncratic needs - a possibility offered by the manufacturer's operational capability of MC. This research gap is somewhat surprising, considering the growing popularity of MC in 
IJOPM 40,11 many industries and recalls Li and Wyer's (1994, pp. 187-188) words: "country-of-origin effects are not clearly understood under many conditions in which products are evaluated." Many years have passed since this remark was made, and the $\mathrm{COO}$ effect has been examined in a variety of contexts (Carlsson Hauff and Nilsson, 2017). Yet, the present study is the first to investigate this effect under the condition that a product is mass-customized rather than mass-produced. The theoretical and empirical results of this study enrich the debate on the moderators of the $\mathrm{COO}$ effect by indicating the operational capability of $\mathrm{MC}$ as another factor that can influence this effect.

\subsection{Limitations and future research directions}

Several limitations of the present study must be acknowledged, which represent opportunities for further research. First, the research hypothesis was tested in a specific sample. This is acceptable for theory-testing purposes, as theory testing calls for falsification procedures: "The research sample need only allow a test of the theory. And, any sample within the theory's domain (e.g. any relevant sample), not just a representative one, can provide such a test" (Calder et al., 1981, p. 200). Nonetheless, the specificity of our sample inevitably limits the generalizability of the effects detected in this study, and therefore, future research should seek to replicate the results with other samples. For example, future studies could investigate whether the effect of MC would remain the same as that observed in this work if the sample of consumers was drawn from a non-Western population rather than Westerners, who tend to emphasize the fulfillment of their personal goals and desires (Riemer et al., 2014).

Second, the research hypothesis was tested using a specific product stimulus. Sneakers fall within the category of self-expressive goods (Franke and Hader, 2014), also known as value-expressive goods (Locander and Spivey, 1978), which are consumer products that, because of the relevance of their aesthetic properties (Franke and Hader, 2014), lend themselves to giving positive expression to a consumer's self-concept (Locander and Spivey, 1978). This kind of product could reinforce the priming of personal identity that MC inherently brings about. If this conjecture is correct, then the mitigation of in-group bias should be stronger when the $\mathrm{MC}$ concept is applied to self-expressive products than when it involves other types of consumer goods, such as personal computers. However, the testing of this hypothesis, which would require manipulating the self-expressiveness benefit that consumers derive from different types of mass-customized products (cf. Merle et al., 2010), is left for further research. Likewise, it would be possible to extend the present study to industrial goods. As buyers of industrial goods do not purchase for themselves, one could expect that the findings of this study are of little relevance to business-to-business contexts. Although reasonable, this conjecture should, nonetheless, undergo empirical scrutiny.

Third, the research hypothesis was tested using two specific source countries: Germany and Italy. As explained in Section 3.2, we purposefully selected two developed nations that ranked high in the "Made in" ranking list to alleviate the risk that cognitive mechanisms would have a confounding effect in the experiment. Future research could investigate whether the effect of MC would remain the same as that observed in this study if one or both of the source countries were a less developed nation with a less favorable image. By doing so, future research would help determine whether $\mathrm{MC}$ can help products from developing economies to overcome negative national stereotypes - with their cognitive, affective and normative connotations (Chattalas et al., 2008) - among consumers who live in more developed countries. Clearly, addressing this question will require consideration of the cognitive and affective mechanisms behind the COO effect.

Another interesting opportunity for further research would be to examine how MC influences the $\mathrm{COO}$ effect at varying levels of consumer-perceived complexity of the product customization task. Prior research has shown that too many customization options, as well as tradeoffs 
between attractive levels of different product attributes, may cause consumers to experience information overload and selection difficulty (e.g. Gourville and Soman, 2005). The existing literature also suggests that the $\mathrm{COO}$ cue may function as a simplifying heuristic for inferring product quality when the amount of information about intrinsic attributes is large and difficult to integrate (Hong and Wyer, 1989; Li and Wyer, 1994). Therefore, one could conjecture that, whenever consumers find the product customization task excessively complex, a cognitive mechanism comes into play whereby $\mathrm{MC}$ strengthens the impact of the $\mathrm{COO}$ cue on perceived product quality. In this case, the reinforcement of the $\mathrm{COO}$ effect through this cognitive mechanism could offset the mitigation of the same effect that this study has theoretically hypothesized, based on a normative mechanism, and empirically demonstrated in an experiment that alleviated the risk of confounding effects of a cognitive nature. Clearly, the theoretical and empirical examination of this conjecture will require investigating the $\mathrm{COO}$ effect from an information-processing perspective (cf. Hong and Wyer, 1989) as well as manipulating the consumer-perceived complexity of the product customization task.

In summary, if the generalizability of the results of the present study is to be better understood, this new line of inquiry on the impact of $\mathrm{MC}$ on the COO effect should be extended in many directions. Examining other combinations of product type, $\mathrm{COO}$ and country of destination as well other mechanisms underlying the COO effect is crucial for assessing the potential of $\mathrm{MC}$ to overcome the intangible barrier constituted by consumer bias based on a product's COO. Eventually, this will enable future research to develop a framework that assists companies - especially those that produce and sell globally - in making the intertwined decisions on $\mathrm{COO}$ and $\mathrm{MC}$ for each of their different geographical target markets.

\subsection{Managerial implications}

Although a framework to support decision-making remains an objective for future research, we believe that the results of this study are of interest to practitioners for at least two reasons: first, the globalization of markets (Cheng et al., 2015), and second, the difficulty a firm may encounter in persuading foreign customers to trust its products when similar goods are made in their home country (Brooks, 2019). Even for globally leading brands, such as Coca-Coca, local competition can be challenging. For example, both the Austrian brand Almdudler, with about 20\% (Coca-Cola Österreich, 2019), and the Swiss brand Rivella, with about 16\% (Schultz, 2019), have a considerable market share in their respective home countries. Local brands can even outperform global competition, as witnessed by the Scottish brand Irn-Bru, often referred to as "Scotland's other national drink" besides whisky (Dew, 2018), which is the best-selling brand in Scotland and the third most popular in the UK (Hosie, 2018).

In this context, the present paper has an interesting message for managers: a firm's operational capability of MC supports expansion into foreign markets not only by reducing the costs of product adaptation for the export markets - as implied by prior research - but also by countering the liability of foreignness of the firm's products, at least for the combinations of product, $\mathrm{COO}$ and target customers considered in this study. Undeniably, firms providing products other than sneakers, made in countries other than Germany or Italy and targeted to customers other than native German- and native Italian-speaking STs should investigate whether this value creation mechanism also applies to their case. However, if it does, the mitigation of the liability of foreignness would be an additional benefit - besides the ones recognized in the extant literature - that might contribute to justifying the companies' efforts to develop their operational capability of MC.

\section{Notes}

1. Compared with theST population, the sample was slightly biased in favor of male, younger and more educated people. 
IJOPM

40,11
2. To understand whether sneaker model influenced the results of the experiment, another betweensubject factor, which describes the two combinations of sneaker model and $\mathrm{COO}$ that were used in the experiment, was initially included in the analysis as a control variable. No significant effect of this variable was found $(p>0.10)$, indicating that the sneaker model had not influenced consumers' product quality perceptions in the experiment.

\section{References}

Addis, M. and Holbrook, M.B. (2001), "On the conceptual link between mass customisation and experiential consumption: an explosion of subjectivity", Journal of Consumer Behaviour, Vol. 1 No. 1 , pp. 50-66.

Aichner, T. and Coletti, P. (2013), "Customers' online shopping preferences in mass customization", Journal of Direct, Data and Digital Marketing Practice, Vol. 15 No. 1, pp. 20-35.

Anderson, J.C., Cleveland, G. and Schroeder, R.G. (1989), "Operations strategy: a literature review”, Journal of Operations Management, Vol. 8 No. 2, pp. 133-158.

Balabanis, G., Mueller, R. and Melewar, T.C. (2002), "The human values' lenses of country of origin images", International Marketing Review, Vol. 19 No. 6, pp. 582-610.

Barnes, D. and Rowbotham, F. (2004), "Testing the four-stage model of the strategic role of operations in a UK context", International Journal of Operations and Production Management, Vol. 24 No. 7, pp. 701-720.

Belk, R.W. (1988), "Possessions and the extended self", Journal of Consumer Research, Vol. 15 No. 2, pp. 139-168.

Bloemer, J., Brijs, K. and Kasper, H. (2009), "The CoO-ELM model—a theoretical framework for the cognitive processes underlying country of origin-effects", European Journal of Marketing, Vol. 43 Nos 1/2, pp. 62-89.

Boyer, K.K. and Lewis, M.W. (2002), "Competitive priorities: investigating the need for trade-offs in operations strategy", Production and Operations Management, Vol. 11 No. 1, pp. 9-20.

Brewer, M.B. and Gardner, W. (1996), "Who is this 'we'? Levels of collective identity and self representations", Journal of Personality and Social Psychology, Vol. 71 No. 1, pp. 83-93.

Brijs, K., Bloemer, J. and Kasper, H. (2011), "Country-image discourse model: unraveling meaning, structure, and function of country images", Journal of Business Research, Vol. 64 No. 12, pp. 1259-1269.

Brooks, C. (2019), "Going global: how to expand your business internationally", Business News DailySmall Business Solutions and Inspiration, Vol. 8 No. May, available at: https://www. businessnewsdaily.com/8211-expand-business-internationally.html (accessed 24 October 2019).

Calantone, R.J., Cavusgil, S.T., Schmidt, J.B. and Shin, G.C. (2004), "Internationalization and the dynamics of product adaptation - an empirical investigation", Journal of Product Innovation Management, Vol. 21 No. 3, pp. 185-198.

Calder, B.J., Phillips, L.W. and Tybout, A.M. (1981), “Designing research for application”, Journal of Consumer Research, Vol. 8 No. 2, pp. 197-207.

Capozza, D. and Manganelli Rattazzi, A.M. (1999), "Stereotypes and attribution processes in a multiethnic Italian province", Journal of Community and Applied Social Psychology, Vol. 9 No. 3, pp. 231-235.

Carlsson Hauff, J. and Nilsson, J. (2017), "The impact of country-of-origin cues on consumer investment behavior: the moderating influence of financial brand strength and investment management style", European Journal of Management, Vol. 51 No. 2, pp. 349-366.

Chang, C.C., Chen, H.Y. and Huang, I.C. (2009), "The interplay between customer participation and difficulty of design examples in the online designing process and its effects on customer satisfaction: mediational analyses", CyberPsychology and Behavior, Vol. 12 No. 2, pp. 147-154. 
Chao, P. (1998), "Impact of country-of-origin dimensions on product quality and design quality perceptions", Journal of Business Research, Vol. 42 No. 1, pp. 1-6.

Charness, G., Gneezy, U. and Kuhn, M.A. (2012), "Experimental methods: between-subject and withinsubject design", Journal of Economic Behavior \& Organization, Vol. 81 No. 1, pp. 1-8.

Chatha, K.A. and Butt, I. (2015), "Themes of study in manufacturing strategy literature", International Journal of Operations and Production Management, Vol. 35 No. 4, pp. 604-698.

Chattalas, M., Kramer, T. and Takada, H. (2008), "The impact of national stereotypes on the country of origin effect: a conceptual framework", International Marketing Review, Vol. 25 No. 1, pp. 54-74.

Mass

and $\mathrm{COO}$

effects

Cheng, Y., Farooq, S. and Johansen, J. (2015), "International manufacturing network: past, present, and future", International Journal of Operations \& Production Management, Vol. 35 No. 3, pp. 392-429.

Coca-Cola Österreich (2019), "Fanta ist bei Limonaden die Nummer zwei in Österreich", Coca-Cola Österreich News, Vol. 25 January, available at: https://www.coca-cola-oesterreich.at/uber-uns/ presseaussendungen/fanta-ist-bei-limonaden-die-nummer-zwei-in-oesterreich (accessed 20 May 2020).

Cohen, M.A. and Lee, H.L. (1989), "Resource deployment analysis of global manufacturing and distriubution networks", Journal of Manufacturing and Operations Management, Vol. 2, pp. 81-104.

Costarelli, S. and Colloca, P. (2004), "Intergroup conflict, out-group derogation, and self-directed negative affect among Italian South Tyroleans", The Journal of Social Psychology, Vol. 144 No. 2, pp. 181-189.

D'Alessandro, S. and Pecotich, A. (2013), "Evaluation of wine by expert and novice consumers in the presence of variations in quality, brand and country of origin cues", Food Quality and Preference, Vol. 28 No. 1, pp. 287-303.

da Silveira, G.J.C. and Sousa, R.S. (2010), "Paradigms of choice in manufacturing strategy_exploring performance relationships of fit, best practices, and capability-based approaches", International Journal of Operations and Production Management, Vol. 30 No. 12, pp. 1219-1245.

da Silveira, G., Borenstein, D. and Fogliatto, F.S. (2001), "Mass customization: literature review and research directions", International Journal of Production Economics, Vol. 72 No. 1, pp. 1-13.

da Silveira, G.C.J., Fogliatto, F.S. and Fendyur, A. (2016), "Demographics of mass customization: a global study of manufacturing plants", Production, Vol. 26 No. 1, pp. 1-11.

Dew, R. (2018), Customer Experience Innovation: How to Get a Lasting Market Edge, Emerald Publishing, Bingley.

Dodds, W.B., Monroe, K.B. and Grewal, D. (1991), "Effects of price, brand, and store information on buyers' product evaluations", Journal of Marketing Research, Vol. 28 No. 3, pp. 307-319.

Eyers, D.R., Potter, A.T., Gosling, J. and Naim, M.M. (2018), "The flexibility of industrial additive manufacturing systems", International Journal of Operations and Production Management, Vol. 38 No. 12, pp. 2113-2343.

Field, A. and Hole, G. (2003), How to Design and Report Experiments, Sage, London.

Fogliatto, F.S., da Silveira, G.J.C. and Borenstein, D. (2012), "The mass customization decade: an updated review of the literature", International Journal of Production Economics, Vol. 138 No. 1, pp. 14-25.

Franke, N. and Hader, C. (2014), "Mass or only 'niche customization'? Why we should interpret configuration toolkits as learning instruments", Journal of Product Innovation Management, Vol. 31 No. 6, pp. 1214-1234.

Franke, N., Schreier, M. and Kaiser, U. (2010), "The 'I designed it myself' effect in mass customization”, Management Science, Vol. 56 No. 1, pp. 125-140.

FutureBrands (2014), "Made in: the value of country of origin for future brands", 26 January, available at: https://www.futurebrand.com/uploads/CBI-14_15-LR.pdf. 
IJOPM 40,11

Gaertner, L., Sedikides, C., Vevea, J.L. and Iuzzini, J. (2002), “The 'I,' the 'we,' and the 'when': a metaanalysis of motivational primacy in self-definition", Journal of Personality and Social Psychology, Vol. 83 No. 3, pp. 574-591.

Garvin, D.A. (1984), “What does 'product quality' really mean?”, Sloan Management Review, Vol. 26 No. 1, pp. 25-43.

Gineikiene, J., Schlegelmilch, B.B. and Auruskeviciene, V. (2017), “Ours' or 'theirs'? Psychological ownership and domestic products preferences", Journal of Business Research, Vol. 72 No. March, pp. 93-103.

Giroux, H. (2006), "It was such a handy term': management fashions and pragmatic ambiguity", Journal of Management Studies, Vol. 43 No. 6, pp. 1227-1260.

Golder, P.N., Mitra, D. and Moorman, C. (2012), "What is quality? An integrative framework of processes and states", Journal of Marketing, Vol. 76 No. 4, pp. 1-23.

Gourville, J.T. and Soman, D. (2005), "Overchoice and assortment type: when and why variety backfires”, Marketing Science, Vol. 24 No. 3, pp. 382-395.

Güran-Canli, Z. and Maheswaran, D. (2000), "Cultural variations in country of origin effects", Journal of Marketing Research, Vol. 37 No. 3, pp. 309-317.

Han, C.M. (1989), “Country image: halo or summary construct?", Journal of Marketing Research, Vol. 26 No. 2, pp. 222-229.

Hayes, R.H. and Wheelwright, S.C. (1984), Restoring Our Competitive Edge: Competing through Manufacturing, John Wiley, New York, NY.

Herz, M.F. and Diamantopoulos, A. (2013), "Activation of country stereotypes: automaticity, consonance, and impact", Journal of the Academy of Marketing Science, Vol. 41 No. 4, pp. 400-417.

Hogg, M.A. and Turner, J.C. (1987), "Intergroup behaviour, self-stereotyping, and the salience of social categories", British, Journal of Social Psychology, Vol. 26 No. 4, pp. 325-340.

Hong, S.T. and Wyer, R.S.J. (1989), "Effects of country-of-origin and product-attribute information on product evaluation: an information processing perspective", Journal of Consumer Research, Vol. 16 No. 2, pp. 175-187.

Hornsey, M.J. (2008), "Social identity theory and self-categorization theory: a historical review", Social and Personality Psychology Compass, Vol. 2 No. 1, pp. 204-222.

Hosie, R. (2018), “Irn-Bru: 15 things you didn’t know about Scotland's national drink”, Independent, Vol. 5 January, available at: https://www.independent.co.uk/life-style/food-and-drink/irn-bruthings-what-is-didnt-know-recipe-change-ag-barr-scotland-favourite-soft-drink-can-a8143301. html (accessed 20 May 2020).

House, R.J., Hanges, P.J., Javidan, M., Dorfman, P.T. and Gupta, V. (2004), Culture, Leadership and Organizations - The Globe Study of 62 Societies, SAGE Publications, Thousand Oaks, California, CA.

International Monetary Fund World Economic Outlook (2015), "World GDP (nominal) ranking”, 21 April, available at: http://statisticstimes.com/economy/world-gdp-ranking.php.

Johansson, M. and Olhager, J. (2018), "Comparing offshoring and backshoring: the role of manufacturing site location factors and their impact on post re-location performance", International Journal of Production Economics, Vol. 205 November, pp. 37-46.

Kache, F. and Seuring, S. (2017), "Challenges and opportunities of digital information at the intersection of Big Data Analytics and supply chain management”, International Journal of Operations and Production Management, Vol. 37 No. 1, pp. 10-36.

Koh, L., Orzes, G. and Jia, F.J. (2019), "The fourth industrial revolution (Industry 4.0): technologies disruption on operations and supply chain management", International Journal of Operations and Production Management, Vol. 39 Nos 6/7/8, pp. 817-828.

Kortmann, S., Gelhard, C., Zimmermann, C. and Piller, T.F. (2014), "Linking strategic flexibility and operational efficiency: the mediating role of ambidextrous operational capabilities", Journal of Operations Management, Vol. 32 November, pp. 475-490. 
Lantz, G. and Loeb, S. (1996), "Country of origin and ethnocentrism: an analysis of Canadian and American preferences using social identity theory", in Corfman, K.P. and LynchJr, J.G. (Eds), NA-Advances in Consumer Research Volume 23, Association for Consumer Research, Provo, pp. 374-378.

Lantz, G. and Loeb, S. (1998), "An examination of the community identity and purchase preferences using the social identity approach", in Alba, J.W. and Hutchinson, J.W. (Eds), NA-Advances in Consumer Research Volume 25, Association for Consumer Research, Provo, pp. 486-491.

Laroche, M., Papadopoulos, N., Heslop, L. and Bergeron, J. (2003), "Effects of subcultural differences on country and product evaluations", Journal of Consumer Behaviour, Vol. 2 No. 3, pp. 232-247.

Laroche, M., Papadopoulos, N., Heslop, L.A. and Mourali, M. (2005), "The influence of country image structure on consumer evaluations of foreign products", International Marketing Review, Vol. 22 No. 1, pp. 96-115.

Lewin, A.Y., Okumura, A., Sakano, T. and Valikangas, L. (1998), "Managing global competition: Japanese companies in transition", Seoul Journal of Business, Vol. 4 No. 2, pp. 1-25.

Leyer, M., Richter, A. and Steinhüser, M. (2019), "'Power to workers' - empowering shop floor workers with worker-centric digital designs", International Journal of Operations and Production Management, Vol. 39 No. 1, pp. 24-42.

Li, W.K. and Wyer, R.S.J. (1994), "The role of country of origin in product evaluations: informational and standard-of-comparison effects", Journal of Consumer Psychology, Vol. 3 No. 2, pp. 187-212.

Locander, W.B. and Spivey, W.A. (1978), “A functional approach to attitude measurement”, Journal of Marketing Research, Vol. 15 No. 4, pp. 576-587.

Lowson, R.H. (2002), "Operations strategy: genealogy, classification and anatomy", International Journal of Operations and Production Management, Vol. 22 No. 10, pp. 1112-1129.

MacCarthy, B.L. and Atthirawong, W. (2003), "Factors affecting location decisions in international operations - a Delphy study", International Journal of Operations and Production Management, Vol. 23 No. 7, pp. 784-818.

Merle, A., Chandon, J.L., Roux, E. and Alizon, F. (2010), "Perceived value of the mass-customized product and mass customization experience for individual consumers", Production and Operations Management, Vol. 19 No. 5, pp. 503-514.

Moser, K. and Piller, F.T. (2006), "The international mass customisation case collection: an opportunity for learning from previous experiences", International Journal of Mass Customisation, Vol. 1 No. 4, pp. 403-409.

Nasser-Abu Alhija, F. and Wisenbaker, J. (2006), "A Monte Carlo study investigating the impact of item parceling strategies on parameter estimates and their standard errors in CFA", Structural Equation Modeling, Vol. 13 No. 2, pp. 204-228.

Norman, G. (2010), "Likert scales, levels of measurement and the 'laws' of statistics", Advances in Health Sciences Education: Theory and Practice, Vol. 15 No. 5, pp. 625-632.

Olson, J.C. and Jacoby, J. (1972), "Cue utilization in the quality perception process", in Venkatesan, M. (Ed.), Proceedings of the Third Annual Conference of the Association for Consumer Research, Association for Consumer Research, Chicago, IL, pp. 167-179.

Peterson, R.A. and Jolibert, A.J.P. (1995), "A meta-analysis of country-of-origin effects”, Journal of International Business Studies, Vol. 26 No. 4, pp. 883-900.

Pierce, J.L. and Jussila, I. (2010), "Collective psychological ownership within the work and organizational context: construct introduction and elaboration", Journal of Organizational Behavior, Vol. 31 No. 6, pp. 810-834.

Pierce, J.L., Kostova, T., Dirks, K. and Olin, J.M. (2003), “The state of psychological ownership: integrating and extending a century of research", Review of General Psychology, Vol. 7 No. 1, pp. 84-107.

Pilkington, A. and Meredith, J.R. (2018), "The diffusion network of research knowledge in operations management", International Journal of Operations and Production Management, Vol. 38 No. 2, pp. 333-349. 
IJOPM

40,11

Piller, F.T., Moeslein, K. and Stotko, C.M. (2004), "Does mass customization pay? An economic approach to evaluate customer integration", Production Planning and Control, Vol. 15 No. 4, pp. 435-444.

Pine, B.J.I. (1993), Mass Customization: The New Frontier in Business Competition, Harvard Business School Press, Boston, MA.

Pine, B.J.I., Victor, B. and Boynton, A.C. (1993), "Making mass customization work”, Harvard Business Review, Vol. 71 No. 5, pp. 108-118.

Reeves, C.A. and Bednar, D.A. (1994), "Defining quality: alternatives and implications”, The Academy of Management Review, Vol. 13 No. 3, pp. 419-445.

Reid, A. and Deaux, K. (1996), "Relationship between social and personal identities: segregation or integration?", Journal of Personality and Social Psychology, Vol. 71 No. 6, pp. 1084-1091.

Riemer, H., Shavitt, S., Koo, M. and Markus, H.R. (2014), "Preferences don't have to be personal: expanding attitude theorizing with a cross-cultural perspective”, Psychological Review, Vol. 121 No. 4, pp. 619-648.

Rudberg, M. and Olhager, J. (2003), "Manufacturing networks and supply chains: an operations strategy perspective", Omega, Vol. 31 No. 1, pp. 29-39.

Sandrin, E., Trentin, A., Grosso, C. and Forza, C. (2017), "Enhancing the consumer-perceived benefits of a mass-customized product through its online sales configurator: an empirical examination", Industrial Management and Data Systems, Vol. 117 No. 6, pp. 1295-1315.

Sandrin, E., Trentin, A. and Forza, C. (2018), "Leveraging high-involvement practices to develop mass customization capability: a contingent configurational perspective", International Journal of Production Economics, Vol. 196 February, pp. 335-345.

Schooler, R. (1971), "Bias phenomena attendant to the marketing of foreign goods in the US", Journal of International Business Studies, Vol. 2 No. 1, pp. 71-80.

Schultz, E. (2019), Entwicklung der Marktanteile der Rivella AG am Süßgetränkemarkt in der Schweiz in den Jahren 2009 bis 2018, Statista, March, available at: https:/de.statista.com/statistik/daten/ studie/532645/umfrage/marktanteil-von-rivella-am-suessgetraenkemarkt-in-der-schweiz/ (accessed 20 May 2020).

Seltman, H.W. (2012), Experimental Design and Analysis, Carnegie Mellon University, Pittsburgh, PA.

Simon, B. and Hamilton, D.L. (1994), "Self-stereotyping and social context: the effects of relative ingroup size and in-group status", Journal of Personality and Social Psychology, Vol. 66 No. 4, pp. 699-711.

Skinner, W. (1969), "Manufacturing-missing link in corporate strategy", Harvard Business Review, Vol. 47 No. 3, pp. 136-145.

Sousa, R. and da Silveira, G.J.C. (2019), "The relationship between servitization and product customization strategies", International Journal of Operations and Production Management, Vol. 39 No. 3, pp. 454-474.

Sousa, R. and Voss, C.A. (2002), "Quality management re-visited: a reflective review and agenda for future research", Journal of Operations Management, Vol. 20 No. 1, pp. 91-109.

Spielmann, N. (2016), "Is it all or nothing? Testing schema congruity and typicality for products with country origin", Journal of Business Research, Vol. 69 No. 3, pp. 1130-1137.

Squire, B., Brown, S., Readman, J. and Bessant, J. (2006), "The impact of mass customisation on manufacturing trade-offs", Production and Operations Management, Vol. 15 No. 1, pp. 10-21.

Stone-Romero, E.F., Stone, D.L. and Grewal, D. (1997), "Development of a multidimensional measure of perceived product quality", Journal of Quality Management, Vol. 2 No. 1, pp. 87-111.

Suzic, N., Forza, C., Trentin, A. and Anisic, Z. (2018), "Implementation guidelines for mass customization: current characteristics and suggestions for improvement", Production Planning and Control, Vol. 29 No. 10, pp. 856-871. 
Swaminathan, V., Page, K.L. and Güran-Canli, Z. (2007), "My' brand or 'our' brand: the effects of brand relationship dimensions and self-construal on brand evaluations", Journal of Consumer Research, Vol. 34 No. 2, pp. 248-259.

Swink, M. and Way, M.H. (1995), "Manufacturing strategy: propositions, current research, renewed directions", International Journal of Operations and Production Management, Vol. 15 No. 7, pp. 4-26.

Tajfel, H. (1978), Differentiation between Social Groups: Studies in the Social. Psychology of Intergroup Relations, Academic Press, London.

Tajfel, H. and Turner, J.C. (1986), "The social identity theory of intergroup behavior", in Worchel, S. and Austin, W.G. (Eds), Psychology of Intergroup Relations, Nelson-Hall Publishers, Chicago, IL, pp. 7-24.

Taverna, L., Bornstein, M.H., Putnick, D.L. and Axia, G. (2011), "Adaptive behaviors in young children: a unique cultural comparison in Italy", Journal of Cross-Cultural Psychology, Vol. 42 No. 3, pp. 445-465.

Trentin, A., Perin, E. and Forza, C. (2014), "Increasing the consumer-perceived benefits of a masscustomization experience through sales-configurator capabilities", Computers in Industry, Vol. 65 No. 4, pp. $693-705$.

Trentin, A., Somià, T., Sandrin, E. and Forza, C. (2019), "Operations managers' individual competencies for mass customization", International Journal of Operations and Production Management, Vol. 39 Nos 9/10, pp. 1025-1052.

Tseng, T.-H. and Balabanis, G. (2011), "Explaining the product-specificity of country-of-origin effects", International Marketing Review, Vol. 28 No. 6, pp. 581-600.

Turner, J.C. and Reynolds, K.J. (2012), "Self-categorization theory”, in Van Lange, P.A.M., Kruglanski, A.W. and Higgins, E.T. (Eds), Handbook of Theories of Social Psychology, SAGE Publications, London, pp. 399-417.

Turner, J.C., Hogg, M.A., Oakes, P.J., Reicher, S.D. and Wetherell, M.S. (1987), Rediscovering the Social Group: A Self-Categorization Theory, Blackwell, New York, NY.

Verlegh, P.W.J. and Steenkamp, J.-B.E.M. (1999), “A review and meta-analysis of country-of-origin research”, Journal of Economic Psychology, Vol. 20 No. 5, pp. 521-546.

Voss, C.A. (1995), "Alternative paradigms for manufacturing strategy", International Journal of Operations and Production Management, Vol. 15 No. 4, pp. 5-16.

Voss, C.A. (2005), "Paradigms of manufacturing strategy re-visited", International Journal of Operations and Production Management, Vol. 25 No. 12, pp. 1223-1227.

Wang, C.K. and Lamb, C.W.J. (1983), “The impact of selected environmental forces upon consumers' willingness to buy foreign products", Journal of the Academy of Marketing Science, Vol. 11 No. 2, pp. 71-84.

Watson, J.J. and Wright, K. (2000), "Consumer ethnocentrism and attitudes toward domestic and foreign products”, European Journal of Marketing, Vol. 34 Nos 9/10, pp. 1149-1166.

Wheelwright, S.C. (1984), "Manufacturing strategy: defining the missing link", Strategic Management Journal, Vol. 5 No. 1, pp. 77-91.

Wheelwright, S.C. and Hayes, R.H. (1985), “Competing through manufacturing”, Harvard Business Review, Vol. 63 No. 1, pp. 99-109.

Zhang, M., Zhao, X. and Qi, Y. (2014), "The effects of organizational flatness, coordination, and product modularity on mass customization capability", International Journal of Production Economics, Vol. 158 No. December, pp. 145-155. 


\section{IJOPM 40,11}

\section{Appendix}

Figures A1 and A2 show the examples of mass-customized sneakers used as tangible product stimuli, as well as the customization options, for Models A and B, respectively. The customization options and their values were defined based on the analysis of several online sales configurators for sneakers. The corresponding mass-produced sneakers were the same as the ones depicted in the two figures, but without the custom image with photo-realistic colors for Model A, and without the custom text for Model B.

\section{2}

Figure A1.

Customization options and the example of mass-customized sneakers used as a tangible product stimulus for Model A

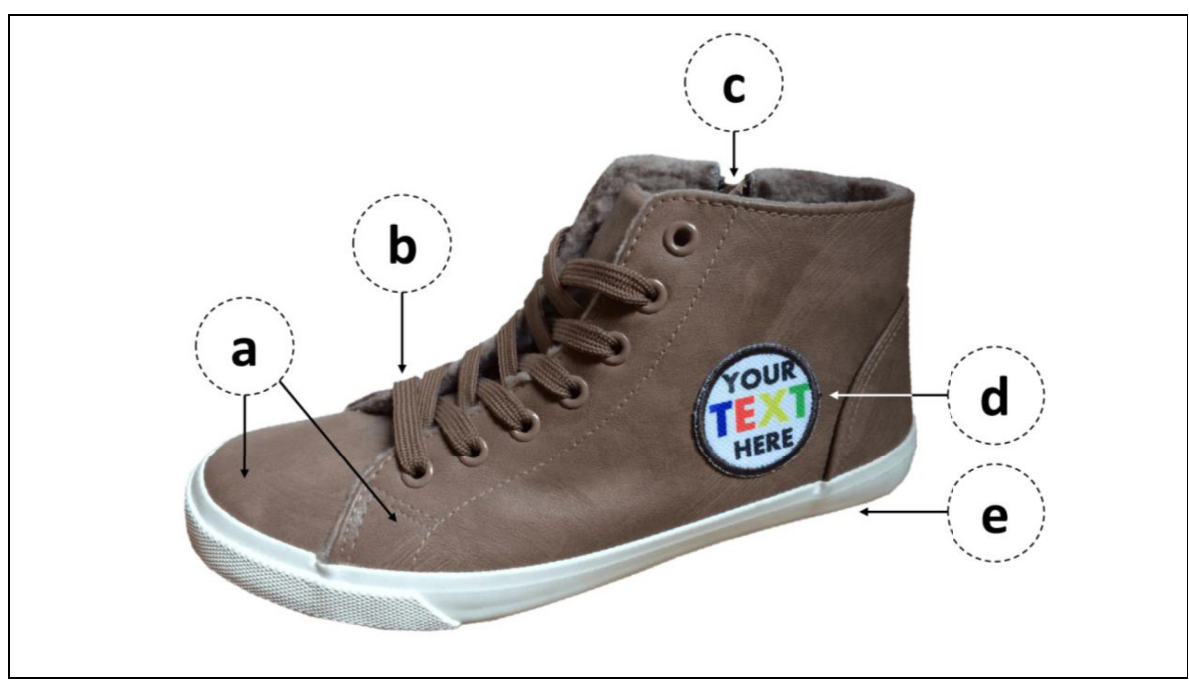

Note(s): $\mathrm{a}=$ color of upper leather (30 available choices); $\mathrm{b}=$ color of shoelaces (22); $\mathrm{c}=$ color of zipper (2); $\mathrm{d}=$ custom text or image with photo-realistic colors; $\mathrm{e}=$ sole material (3) and sole color (5) 


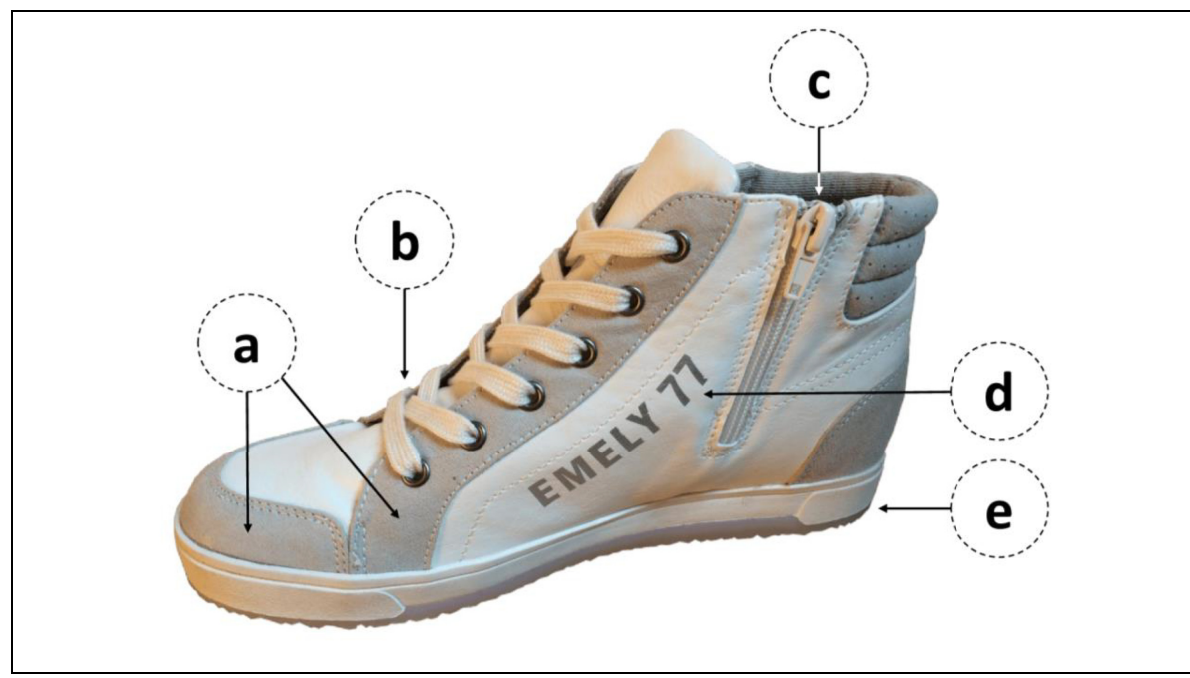

Note(s): $a=$ color of leather stripes (30 available choices); $b=$ color of shoelaces (22); $\mathrm{c}=$ color of zipper (2); $\mathrm{d}=$ custom text (up to 10 symbols) and text color (9); e = sole material (3) and sole color (5)

\section{Corresponding author}

Alessio Trentin can be contacted at: alessio.trentin@unipd.it

\section{Mass \\ customization and $\mathrm{COO}$ effects \\ 1683}

Figure A2.

Customization options and the example of mass-customized sneakers used as a tangible product stimulus for Model B

For instructions on how to order reprints of this article, please visit our website:

www.emeraldgrouppublishing.com/licensing/reprints.htm

Or contact us for further details: permissions@emeraldinsight.com 